\title{
PENGARUH INFLASI, SUKU BUNGA, DAN NILAI TUKAR RUPIAH TERHADAP INDEKS HARGA SAHAM GABUNGAN (IHSG) DI BURSA EFEK INDONESIA
}

\author{
Siska Wahyuni Sukamto \\ Department of Management FEB UMM \\ Email:Cuikha_princess@rocketmail.com
}

\begin{abstract}
This studi was conducted to determine the effect macro economic variable of inflation, interest rate, and exchange rate againts the stock price indeks on indonesia stock exchange, and look for variables that effect most dominant among the three variables in the stock price index. Type of research is quantitative research, using multiple regression analysis, $F$ test, $t$ test and standardized coefficient as a tool of analysis in this study. Results of the study found that the variables inflation, interest rate, and exchange rate either simultaneously is significant effect on stock price index. Either partially the inflation variable has a significant effect on stock price index, while the variable interest rate have a significant negative effect on the stock price index, and the exchange rate has a significant effect on the stock price index, inflation variable are the most dominany effect on stock price index on Indonesia Stock Exchange
\end{abstract}

Keyword: Stock Price Index, Inflation, Interest Rate, Exchange Rate.

\section{PENDAHULUAN}

Kegiatanperekonomian setiap negara tidak selalu stabil, tetapi berubah-ubah akibat berbagai masalah ekonomi yang timbul. Salah satu aspek penting dari kegiatan perekonomian yang menjadi dasar analisis dalam teori ekonomi makro adalah pandangan bahwa sistem pasar bebas tidak dapat mewujudkan kestabilan harga dan pertumbuhan ekonomi yang teguh. Setiap perekonomian tidak terlepas dari berbagai masalah, seperti pengangguran, kenaikan harga dan pertumbuhan ekonomi yang tidak stabil, untuk mengatasi berbagai masalah ekonomi makro di
suatu negara tersebut, maka
pemerintah

perlu membuat kebijakan. Salah satunya adalah membuat kebijakan moneter.

Kebijakan moneter merupakan kebijakan yang dilakukan bank sentral dalam mengatur dan mengendalikan jumlah uang yang beredar (Asfia Murni, 2006), dapat disimpulkan bahwa kebijakan moneter mempengaruhi perekonomian. Kestabilan ekonomi tercermin terutama melalui terkendalinya laju inflasi atau 
terkendalinya laju perubahan tingkat harga barang dan jasa.

Tabel 1. Perkembangan Tingkat Inflasi, Suku Bunga, dan Nilai Tukar Rupiah Periode 2008 - 2014

\begin{tabular}{cccc}
\hline Periode & $\begin{array}{c}\text { Inflasi } \\
(\%)\end{array}$ & $\begin{array}{c}\text { Suku } \\
\text { Bung } \\
\text { a } \\
(\%)\end{array}$ & $\begin{array}{c}\text { Kurs } \\
\text { Tukar } \\
\text { Rp/US } \\
\$\end{array}$ \\
\hline 2008 & 10,27 & 8,62 & 9.725 \\
2009 & 572, & 7,14 & 10.302 \\
2012 & 5,20 & 6,50 & 9.303 \\
2010 & 5,34 & 6,58 & 8.968 \\
2012 & 4,25 & 5,77 & 9.372 \\
2013 & 6,96 & 6,54 & 10.512 \\
2014 & 6,39 & 7,50 & 11.705
\end{tabular}

Sumber: Bank Indonesia periode 2008 - 2014

Berdasarkan data tabel 1 di atas menunjukan bahwa pada tahun 2014 tingkat inflasi di tutup sebesar 6,39\% dengan suku bunga yang tinggi mencapai $7,50 \%$ dan kurs tukar sebesar Rp.11.705 dibandingkan tahun-tahun sebelumnya. Inflasi yang sangat tinggi terjadi di tahun 2008, dimana tingkat inflasi mencapai $10,27 \%$ dan merupakan inflasi tertinggi selama kurun waktu 7 tahun. Suku bunga tertinggi juga terjadi pada tahun 2008 yang mencapai 8,62\%, serta di tahun 2014 kurs tukar merupakan yang tertinngii sebesar Rp. 11.705 naik Rp.1.193 dari tahun 2013 yaitu 10.512 .

Penurunan inflasi sejak tahun 2008 terus terjadi sampai pada tahun 2012 yang kemudian terjadi kenaikan sebesar 2,71\% di tahun 2013 yaitu mencapai $6,96 \%$ di bandingkan tahun sebelumnya, dan kemudian penurunan terjadi di tahun 2014 sebesar $2,43 \%$ menjadi $6,39 \%$. Suku bunga mengalami kenaikan dan penurunan yang fluktuasi dan suku bunga terendah selama kurun waktu 7 tahun terjadi di tahun 2012 yaitu sebesar 5,77\% dibandingkan tahuntahun sebelumnya dan tahun berikutnya, sementara kurs tukar paling rendah terjadi di tahun 2010 yaitu sebesar Rp. 8.968.

Suku bunga adalah harga uang, yang nilainya ditentukan oleh kurva permintaan uang dan penawaran uang. Perubahan kenaikan suku bunga dan inflasi serta melemahnya nilai tukar rupiah memerlukan waktu untuk dapat mengubah biaya produksi, keuntungan perusahaan, dan lebih lanjut harga saham perusahaan di bursa efek.

Setiap negara selalu menjaga agar nilai tukar mata uang domestik negaranya dalam keadaan yang stabil terhadap nilai tukar mata uang asing. Nilai tukar yang stabil mempunyai peran penting dalam rangka tercapainya stabilitas moneter serta mendukung kegiatan ekonomi. Nilai tukar yang stabil diperlukan untuk terciptanya iklim yang kondusif bagi seluruh kegiatan ekonomi. Kestabilan nilai tukar cenderung akan menguatkan harga saham.

Pasar modal merupakan pasar dimana diperjualbelikan instrumen keuangan jangka panjang yang memegang peranan sangat penting dalam perekonomian Indonesia (Tjiptono, 2001), dimana nilai Indeks Harga Saham Gabungan dapat menjadi leading indikator bagi ekonomi suatu negara. Pergerakan indeks sangat dipengaruhi oleh ekspektasi investor atas kondisi fundamental negara maupun global. Indeks harga saham yang mengalami peningkatan dapat mengindikasikan 
adanya perbaikan kinerja perekonomian.

Bedasarkan latar belakang tersebut penulis tertarik untuk melakukan penelitian dengan judul "Pengaruh Inflasi, Suku Bunga, dan Nilai Tukar Rupiah terhadap Indeks Harga Saham Gabungan (IHSG) di Bursa Efek Indonesia”.

\section{TINJAUAN PUSTAKA}

Tri Susilo Anggoro (2011) melakukan penelitian dengan judul Pengaruh Inflasi, Kurs dan Suku Bunga SBI Terhadap Indeks Harga Saham Gabungan Pada Bursa Efek Indonesia Periode 2005-2009. Hasil analisis dapat diketahui bahwa variabel inflasi, kurs, dan suku bunga SBI secara simultan berpengaruh positif signifikan terhadap Indeks Harga Saham Gabungan (IHSG) di Bursa Efek Indonesia, secara parsial variabel inflasi tidak berpengaruh signifikan terhadap IHSG, variabel kurs berpengaruh negatif dan signifikan terhadap IHSG, dan variabel suku bunga SBI berpengaruh negatif dan signifikan terhadap IHSG.

Trisnadi Wijaya (2012) melakukan penelitian dengan judul Analisis Pengaruh Tingkat Inflasi, Tingkat Suku Bunga SBI dan Nilai Tukar Rupiah Terhadap IHSG di Bursa Efek Indonesia periode 20072011. Hasil analisis dapat diketahui bahwa variabel inflasi, suku bunga, dan kurs secara simultan mempengaruhi pergerakan Indeks Harga Saham Gabungan (IHSG) di Bursa Efek Indonesia. Secara parsial tingkat inflasi berpengaruh positif dan signifikan terhadap pergerakan IHSG, dimana semakin tinggi tingkat inflasi, maka IHSG akan naik, tingkat suku bunga SBI berpengaruh negatif dan signifikan terhadap pergerakan IHSG, dimana semakin besar tingkat suku bunga SBI maka IHSG akan turun dan nilai tukar rupiah berpengaruh negatif dan signifikan terhadap IHSG, dimana semakin tinggi nilai tukar rupiah, maka IHSG akan turun.

Perbedaan penelitian ini dan penelitian terdahulu yaitu: 1). Pada penelitian ini selain meneliti pengaruh parsial dan simultan antar variabel bebas juga ingin mengetahui variabel bebas mana yang paling berpengaruh terhadap variabel terikat. 2). Perbedaan periode waktu yang digunakan dalam penelitian. Periode penelitian yang dilakukan Tri Susilo Anggoro (2011) yaitu tahun 20052009 dan oleh Trisnadi Wijaya (2012) periode 2007- 2011, sedangkan penelitian ini mengambil data bulanan periode Januari 2008 September 2014. 3). Suku bunga yang digunakan pada penelitian sebelumnya menggunakan suku bunga SBI sedangkan suku bunga pada penelitian ini menggunakan suku bunga Bank Indonesia (BI rate). Dipilihnya BI rate karena suku bunga inilah yang dijadikan acuan dalam penentuan suku bunga lainnya.

Indeks harga saham adalah suatu indikator yang menunjukan pergerakan saham. Indeks berfungsi sebagai indikator tren pasar, artinya pergerakan indeks akan menggambarkan kondisi pasar pada saat pasar sedang aktif atau tidak. Menurut Djiptono dan Hendy (2001) di pasar modal, sebuah indeks diharapkan memiliki lima fungsi yaitu: Sebagai indikator tren pasar, sebagai indikator tingkat keuntungan, sebagai tolak ukur kinerja portofolio, memfasilitasipembentukan portofolio 
secara strategi pasif, memfasilitasi berkembangnya produk derivative.I IHSG pertama kali diperkenalkan pada tanggal 1 April 1983 sebagai indikator pergerakan harga saham yang tercatat di BEI baik saham biasa maupun preferen. Indeks harga adalah suatu angka yang digunakan untuk melihat perubahan mengenai harga dalam waktu dan tempat yang sama ataupun berlainan. Indeks adalah ukuran statistik yang biasanya digunakan dalam menyatakan perubahan perbandingan nilai suatu variabel tunggal atau nilai sekelompok variabel, umumnya mengetahui besarnya Indeks Harga Saham Gabungan.

Harga saham yang mengalami perubahan setiap harinya membuat investor harus mampu memperhatikan faktor-faktor yang mempengaruhi harga saham. Faktorfaktor yang mempengaruhi fluktuasi harga saham dapat berasal dari internal maupun eksternal (Indah Yuliana, 2010), adapun faktor internalnya antara lain adalah laba perusahaan, pertumbuhan aktiva tahunan, likuiditas, nilai kekayaan total, dan penjualan. faktor eksternalnya adalah kebijakan pemerintah dan dampaknya, pergerakan suku bunga, inflasi, fluktuasi nilai tukar mata uang, rumor dan sentimen pasar.

Dwi Eko Waluyo (2006) mendefinisikan inflasi sebagai kecenderungan kenaikan harga-harga umum secara terus menerus. Pengertian kenaikan harga satu atau beberapa macam barang pada suatu saat tertentu dan hanya "sementara" belum tentu menimbulkan inflasi.
Sejak awal juli 2005, Bank Indonesia menggunakan mekanisme $\mathrm{BI}$ rate (suku bunga BI), yaitu BI mengumumkan target suku bunga SBI yang diinginkan oleh Bank Indonesia untuk pelelangan pada masa periode tertentu. BI rate adalah suku bunga instrumen sinyaling Bank Indonesia yang ditetapkan pada rapat Dewan Gubernur (www.bi.go.Id).

Menurut Aulia Pohan (2008) perkembangan tingkat bunga yang tidak wajar secara langsung dapat mengganggu perkembangan perbankan. Suku bunga yang tinggi, disatu sisi akan meningkatkan hasrat masyarakat untuk menabung sehingga jumlah dana perbankan akan meningkat. Sementara itu, disisi lain suku bunga yang tinggi akan meningkatannya biaya yang dikeluarkan oleh dunia usaha sehingga mengakibatkan penurunan kegiatan produksi dalam negeri.

Nilai tukar yang melonjaklonjak secara derastis tak terkendali akan menyebabkan kesulitan pada dunia usaha dalam merencanakan usahanya, oleh karena itu pengelolaan nilai mata uang yang cukup stabil menjadi salah satu faktor moneter yang mendukung perekonomian secara makro.

Nilai tukar atau yang sering disebut dengan kurs merupakan salah satu harga yang terpenting dalam perekonomian terbuka mengingat pengaruhnya yang demikian besar bagi neraca transaksi berjalan. Pertukaran antara dua mata uang yang berbeda akan terdapat perbandingan nilai atau harga antara kedua mata uang tersebut. 


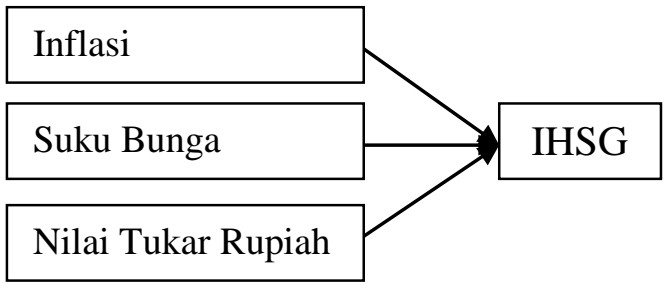

Gambar 1. Kerangka Pikir Penelitian

\section{METODE PENELITIAN}

Penelitian ini menggunakan penelitian deskriptif dengan pendekatan kuantitatif terhadap fenomena tertentu. Penelitian ini memberikan gambaran secara umum tentang bahasan yang diteliti dalam bentuk data atau angka yang kemudian dianalisis, diklasifikasikan, dan diinterprestasikan. Data yang digunakan dalam penelitian ini adalah data kuantitatif. Data kuantitatif adalah data yang berbentuk angka atau bilangan.

Sumber data yang dugunakan dalam penelitian ini adalah data sekunder. Data sekunder adalah data dari hasil pengumpulan orang lain atau pihak lain dengan maksud tertentu dan mempunyai kategorisasi atau klasifikasi tertentu (Soeranto dan Arsyad, 2003), Data sekunder dalam penelitian ini berasal dari Bursa Efek Indonesia yang berada di gedung Fakultas Ekonomi dan Bisnis lantai 4 Universitas Muhammadiyah Malang. Dalam penelitian ini data yang diperoleh dengan teknik dokumentasi. Teknik dokumentasi dilakukan untuk mengumpulkan data sekunder dari berbagai sumber, baik secara pribadi maupun kelembagaan (Sanusi, 2011).

Teknik analisis yang digunakan penelitian ini adalah model persamaan regresi linier berganda. Regresi liner berganda adalah dimana variabel terikatnya (Y) dihubungkan atau dijelaskan lebih dari satu variabel (Iqbal Hasan, 2001).

\section{HASIL PENELITIAN DAN PEMBAHASAN}

Bursa efek merupakan lembaga yang menyelenggarakan kegiatan sekuritas di Indonesia. Bursa efek di Indonesia terbagi menjadi dua, yaitu Bursa Efek Jakarta dan Bursa Efek Surabaya. Bursa Efek Jakarta didirikan oleh pemodal Belanda pada tanggal 14 Desember 1912 dengan nama Vereneging Voor dc Effecttenhandel dengan tujuan untuk menghimpun dana guna menunjang ekspansi usaha perkebunan milik orang-orang Belanda di Indonesia.

Bursa Efek Indonesia (BEI) merupakan bursa hasil penggabungan dari Bursa Efek Jakarta (BEJ) dengan Bursa Efek Surabaya (BES) terhitung mulai 1 Desember 2007 secara resmi Bursa Efek Indonesia telah efektif. Hadirnya Bursa Efek tunggal ini akan diharapkan akan meningkatkan efisiensi industri pasar modal di Indonesia dan menambah daya tarik untuk berinvestasi. Efektif karena penyebaran informasi tidak lagi berasal dari dua Bursa Efek melainkan cukup berasal dari satu Bursa Efek. Pelaku pasar juga hanya mengenal satu Bursa Efek yang memfasilitasi seluruh segmen pasar. Efisiensi tercapai karena perusahaan Efek cukup menadi anggora satu bursa.

Indeks Harga Saham Gabungan merupakan salah satu indeks pasar saham yang digunakan oleh BEI. IHSG pertama kali diperkenalkan pada tanggal 1 April 1983 sebagai 
indikator pergerakan saham yang tercatat di Bursa Efek Indonesia baik saham biasa maupun preferen. Nilai IHSG ditentukan dengan perhitungan berdasarkan nilai, dimana bobot yang lebih besar diberikan pada saham yang berkapitalisasi pasar besar dan bukan pada saham tertinggi.

Hasil pengujian regresi linier berganda dengan menggunakan SPSS (Statistical Product and Service Solution) ini menunjukan bahwa variabel independen inflasi, suku bunga, dan nilai tukar rupiah secara bersama-sama berpengaruh terhadap Indeks Harga Saham Gabungan (IHSG) di Bursa Efek Indonesia selama periode Januari 2008 September 2014.

Hasil ini menunjukan bahwa menilai perubahan pada saham gabungan secara keseluruhan juga perlu dan penting untuk diperhatikan, karena terbukti bahwa indikator ekonomi makro seperti inflasi, suku bunga, dan nilai tukar rupiah memiliki pengaruh sebesar 46,2\%.

Hasil uji $F$ (simultan) dalam penelitian ini konsisten seperti hasil dari penelitian yang dilakukan oleh Tri Susilo Anggoro dan Trisnadi Wijaya bahwa variabel inflasi, suku bunga, dan nilai tukar rupiah berpengaruh secara bersama-sama atau simultan.

Berdasarkan uji $t$ dengan melihat hasil uji parsial (uji t), maka dapat diketahui bahwa variabel independen (inflasi) berpengaruh positif terhadap variabel dependen yaitu Indeks Harga Saham Gabungan. Hal ini disebabkan karena melihat parah tidaknya inflasi yang terjadi, apabila inflasi ringan maka akan berampak positif bagi perekonomian dan sebaliknya apabila inflasi tinggi (hyperinflasi) maka akan berdampak negatif. Keadaan fundamental ekonomi dalam negeri yang stabil juga memberikan dampak positif terhadap IHSG.

Hasil uji parsial (uji t) dalam penelitian ini konsisten dengan penelitian yang dilakukan oleh Trisnadi Wijaya bahwa variabel inflasi berpengaruh positif dan signifikan terhadap IHSG, namun hasil penelitian ini menolak atau berbeda dengan hasil penelitian yang telah dilakukan oleh Tri Susilo Anggoro yang menyatakan bahwa variabel inflasi tidak berpengaruh signifikan terhadap IHSG.

Variabel suku bunga dengan melihat hasil uji parsial (uji t), maka dapat diketahui bahwa variabel independen (suku bunga) berpengaruh negatif terhadap variabel dependen yaitu Indeks Harga Saham Gabungan. Hal ini dikarenakan meningkatnya suku bunga mengakibatkan investor lebih memilih menyimpan uangnya di bank dari pada memilih berinvestasi di pasar saham, sehingga menyebabkan harga saham menurun.

Hasil uji parsial (uji t) dalam penelitian ini konsisten dengan penelitian yang dilakukan oleh Tri Susilo Anggoro dan Trisnadi Wijaya yang menyatakan bahwa variabel suku bunga berpengaruh negatif dan signifikan terhadap IHSG.

Variabel nilai tukar rupiah dengan melihat hasil uji parsial (uji t), maka dapat diketahui bahwa variabel independen (nilai tukar rupiah) berpengaruh positif terhadap variabel dependen yaitu Indeks Harga Saham Gabungan. Hal ini bisa terjadi dikarenakan melihat dari tipe investor itu sendiri atau dengan melihat porsi 
kepemilikan saham di BEI yang di dominasi oleh asing, yaitu apabila investor berasal dari luar dan menggunakan mata uang asing. Bagi investor luar, terdepresiasinya mata uang rupiah akan menyebabkan investor cenderung melepas mata uang asingnya untuk membeli saham yang harganya turun karena pengaruh kurs mata uang.

Hasil uji parsial (uji t) dalam penelitian ini berbeda dengan penelitian yang dilakukan oleh Tri Susilo Anggoro dan Trisnadi Wijaya yang menyatakan bahwa variabel nilai tukar rupiah berpengaruh negatif dan signifikan terhadap IHSG.

Berdasarkan hasil analisis yang telah dilakukan, dapat dibuktikan bahwa variabel inflasi yang dominan mempengaruhi Indeks Harga Saham Gabungan di Bursa Efek Indonesia karena semakin tinggi tingkat inflasi maka IHSG akan naik, sedangkan apabila terjadi penurunan pada inflasi, maka akan menurunkan IHSG di Bursa Efek Indonesia.

\section{SIMPULAN}

Berdasarkan hasil penelitian dan pembahasan maka dapat diambil kesimpulan bahwa: Uji regresi secara simultan (Uji F) menunjukan bahwa ketiga variabel independen di atas secara bersama-sama mampu mempengaruhi Indeks Harga Saham Gabungan di Bursa Efek Indonesia. Uji regresi secara parsial (Uji t) dapat dinyatakan bahwa: Variabel inflasi berpengaruh positif terhadap IHSG, variabel suku bunga berpengaruh negatif terhadap IHSG, variabel nilai tukar rupiah berpengaruh positif terhadap IHSG.

Hasil analisis regresi menunjukan bahwa variabel yang dominan berpengaruh terhadap IHSG adalah variabel inflasi.

\section{DAFTAR PUSTAKA}

Darmadji, Tjiptono dan Fakhrudin, H,M. 2001. Pasar Modal di Indonesia Pendekatan Tanya Jawab. Jakarta: Salemba Empat.

Hasan, Iqbal. 2001. Pokok-pokok Materi Statistik 2. Edisi Kedua. Jakarta: PT Bumi Aksara.

Murni, Asfia. 2006. Ekonomi Makro. Jakarta: PT Refika Aditama.

Pohan, Aulia. 2008. Potret Kebijakan Moneter Indonesia. Edisi 1. Jakarta: PT Raja Grafin Pustaka.

Sanusi, Anwar. 2011. Metodelogi Penelitian Bisnis. Jilid 1. Jakarta: Salemba Empat.

Santoso, Singgih. 2002. Riset Pemasaran Konsep dan Aplikasi dengan SPSS. Jakarta: PT Gramedia.

Anggoro, Susilo Tri. 2011. Pengaruh Inflasi, Kurs dan Suku Bunga SBI terhadap Indeks Harga Saham Gabungan pada Bursa Efek Indonesia periode 20052009. Skripsi. Surakarta: Universitas Sebelas Maret.

Waluyo, Eko Dwi. 2006. Ekonomika Makro. Malang: UMM Press.

Wijaya, Trisnadi. 2012. Analisis Pengaruh tingkat Inflasi, Tingkat Suku Bunga, dan Nilai Tukar Rupiah terhadap IHSG di Bursa Efek Indonesia periode 2007-2011. Jurnal.

Yuliana, Indah. 2010. Investasi Produk Keuangan Syariah. Malang: UIN-MALIKI PRESS (Anggota IKAPI). 